\title{
LOCAL EXPERT EXPERIENCES AND PERCEPTIONS OF ENVIRONMENTALLY INDUCED MIGRATION FROM BANGLADESH TO INDIA
}

\begin{abstract}
This study investigates local expert perceptions of the role of environmental factors, especially in terms of contemporary climate change, in population movements from Bangladesh to India. The aim is to delve into locally held understandings of the phenomenon and to gain a better understanding of these migration processes that are actively intertwined with local experiences. Both Indian and Bangladeshi experts were interviewed using semi-structured, in-depth interviews in order to explore insights from locally held perceptions and understandings into contextual factors. In total, ten Bangladeshi and fifteen Indian experts were interviewed, covering different disciplines, sectors, regions, and job types, together providing a more complete and grounded picture of views of environmentally induced migration in Bangladesh and India. The results show that climate change is perceived by local experts as one of the key factors influencing migration in Bangladesh, both internally and externally. The interviewees, however, placed environmentally induced migration into a broader context of labour and economic migration. In particular, migration for environmental reasons had happened in Bangladesh long before climate change emerged as an issue. According to the interviewed experts, this does not preclude increased environmentally induced migration in and from Bangladesh in the future, but its analyses ought to be placed into historical and economical contexts.
\end{abstract}

Key words: Climate change, migration, India, Bangladesh, perception

\section{Introduction}

Population movement around, to, and from South Asia is well-documented, with environmental drivers impacting these movements (e.g. Hadi, 1999; Khatri, 2007; Massey et al., 2010; Siddiqui, 2001). Climate change is now particularly prominent and extensively debated as an additional factor influencing migration around the world (e.g. Bettini, 2013; Black et al., 2011; Deshingkar, 2012). The main challenge raised in the literature is that people typically move due to the combination of many environmental, economic and social factors, so decoupling climate change from the myriad of factors is not always easy or helpful.

Bangladesh is often depicted as one of the primary source countries of environmentally induced migration while India is often portrayed as being amongst the primary receiving countries of Bangladeshi migrants (Campbell et al., 2007; GACGC, 2007; CNA, 2007). Such representations have been suggested as oversimplifying the complex connections between environmental change and migration. For instance, most evidence suggests that the majority of migrants affected by environmental change stay within their home countries and move temporarily, while groups which lack resources to move may be forced to stay behind in high-risk areas (Foresight, 2011; Felli and Castree, 2012; Kelman et al. 2015).

This paper aims to shed more light on these discussions and narratives regarding environmentally induced migration from Bangladesh to India, in order to gain a more context-based picture. In order to do so, we engage with local experts' experiences and perspectives. The importance is moving away from the domination of the topic by scholars, non-governmental (NGOs), and think tanks from outside these countries and mainly from more affluent countries (Boas, 2014). The primary objectives of this paper are (i) to analyze experiences and perceptions of local experts regarding the role of environmental factors in population movements in Bangladesh and India, and (ii) to examine to what extent these viewpoints intersect or possibly conflict with findings from the international academic literature. A total of 25 local experts from India and Bangladesh were interviewed, selected from different disciplines, sectors, regions, and job types.

\section{Theory of environmentally induced migration}


Although environmental change has been one significant driver of population movement throughout human history (e.g. Samers, 2010; Smith et al., 2012), Piguete (2010) argues that the topic recently stayed on the periphery of the majority of migration studies. An important reason is that it is difficult to separate environmental factors from economic, political, and other social reasons for moving (Perch-Nielsen et al., 2008; Piguete, 2010; Stojanov, 2012). In the majority of cases, people do not move for a single reason. Additionally, not all environmental degradation or environmental change leads to significant population movement or even to the desire to move. Motivation to move involves a complex web of multiple factors that denote individual beliefs, interests, and dreams along with collective decisions, within specific economic, social, and political contexts (Stojanov et al., 2014). Finally, there is no commonly accepted definition or methodology for estimating, calculating, or classifying people moving for different levels of influence of environmental reasons.

Foresight (2011) and the response by Felli and Castree (2012) explore migration-environment connections due to various environmental change processes. Some geographers have responded to recent trends of environmental change influencing migration decisions by integrating them into migration typologies. For example, Stojanov et al. (2014) formulate a typology of environmentally induced population movement on (i) environmental migrants, (ii) environmental displacees with two subcategories of slow-onset and rapidonset environmental displacees, and (iii) development displacees. This typology provides a basis for considering a wide variety of motives for environmentally induced population movement, in relation to different drivers, motivations, time scales, and space scales.

In recent years, the debate regarding environmentally induced population movement has been dominated by climate change impacts as a main driver. The predictions from IPCC (2013-2014) about future development might or might not come true in the future. In the meantime, a disconnect continues between those pushing the agenda of environmentally induced population movement on the basis of climate change only (Boas 2015) and those taking wider perspectives to understand root causes of people's movement while placing climate change in wider contexts (Stojanov et al., 2014).

Summarizing the literature, climate change and migration is a multi-faceted and dynamic process which is far from being completely understood (see also Upadhyay et al., 2015). It is, as it always has been, a longterm process requiring knowledge from many disciplines and variability of methodological approaches in order comprehend different options, lack of options, responses, and non-responses from the affected population.

\section{Migration in South Asia and Environmental Factors}

For Bangladesh, internal and international migration is common for livelihood reasons and that has been the case for much of its history, including before independence (e.g. Boas, 2015; Donato et al., 2016; Hadi, 1999; Siddiqui, 2001; Van Schendel 2005). Cross-border immigration from Bangladesh (which was East Pakistan from 1947 to 1971) into India became an issue following India's partition in 1947. This region has always been characterized by a high degree of mobility (Van Schendel, 2005; Upadhyaya, 2006; McAdam and Saul, 2010), especially internal given that much of Bangladesh comprises a large and dynamic delta, with coastal subsidence and river channels often morphing. As a result, inhabitants have constantly been moving in search of new land and livelihoods, with environmental change (but not climate change per se) amongst other factors being major influences.

The Indian discourse towards immigrants from Bangladesh was initially rather mild and welcoming, with many seeing them as children coming home, especially if they were Hindus moving after independence and partition (see also Weiner, 1978). This perception gradually changed over the decades. Immigrants, no longer moving directly as a result of the partition, were soon presented as being illegal infiltrators. The later groups of immigrants from Bangladesh were often Muslims and were seen as drastically changing the demographic composition of neighboring areas in India such as Tripura and Assam (Van Schendel, 2005). Recent migration from Bangladesh to India is suggested as being the largest international flow between two sovereign countries because Bangladeshi communities have used migration as a tool to diversify and increase their income (ADB, 2012).

According to the Indian census from 2001, the total number of immigrants in India amounted to 5.1 million, of whom 59\% were from Bangladesh and $97 \%$ were from all of India's neighboring countries 
combined (Census of India, 2001). These are official data which do not include unregistered migration. Most immigrants from Bangladesh to India end up in Assam and West Bengal and it is estimated that there could be as many as six million unregistered immigrants there from Bangladesh (Nath et al., 2012; Goswami, 2010). Given that the total population of Assam province is 26 million, unregistered migration from Bangladesh represents a significant social, economic, and political situation, often termed a "problem" (Goswami, 2010; Kumar, 2010). Some Indian analysts even go so far as to suggest that sending migrants to Assam is an unofficial Bangladeshi policy for colonizing Northeast India (Kumar, 2010). Anti-immigrant sentiment directed at Muslims in Assam is long-standing (Dass, 1980), sometimes turning violent such as in 1983 with thousands being massacred (Weiner, 1983). Singh (2009) reports the Muslim population in the beginning of the $21^{\text {st }}$ Century as $30.9 \%$ compared with $8-9 \%$ in 1950, attributing separatist violence to be a reaction against these immigrants (see also Sinha, 2011).

This is not to argue, however, that all Indian analysts have such a negative view of unregistered Bangladeshi immigrants. There is a counter discourse presenting migration flows as a constant stream of labor supply benefiting India's development (McAdam and Saul, 2010), and there are concerns for the human rights of immigrants, both those deported and those locally affected (Dasgupta et al., 2010). What makes the situation particularly harsh on the immigrants is that the Governments of neither India nor Bangladesh recognize the unregistered immigrants. While India seeks to deport unregistered immigrants, the Bangladeshi government claims that the deported persons are Bengali-speaking Indians (Van Schendel, 2005). In the past, the deportees have often ended up in deportation camps along the Indian border, in jail in West Bengal, or as migrants within India (Van Schendel, 2005).

Authors attribute different roles that environmental factors can play in migration processes, both within Bangladesh and from Bangladesh towards India. Ahmed (2008) suggests that the number of migrants from Bangladesh to India grows during disasters such as floods and droughts in Bangladesh (see also Saadi, 2003) and internal migration has also been shown to increase due to a disaster (Saha, 2016). Zaman (1991) notes that environmental reasons often lead to internal migration in Bangladesh rather than international migration; for example, nearly $88 \%$ of migrant households of Bangladeshi floodplain residents had moved not further than $3.2 \mathrm{~km}$ from their previous residence. Furthermore, population movement in the Bengal region (currently divided between India and Bangladesh) has always been intertwined with environmental factors, even prior to India's partition in 1947, as noted above. The advent of climate change has brought a new environmental factor into the influences on migrating.

The country is characterized by rapid urbanization, high population growth, high population density, and intensive land and resource use for agriculture and industry production, all contributing to high vulnerability to environmental hazards, expected to become more evident under climate change (IPCC, 2013-2014; Khan, 2012; Mirza, 2003). The main environmental changes induced by climate change in Bangladesh are expected to be sea-level rise, worse storm surges, more intense cyclones (although changes to cyclone frequency are uncertain), and changing precipitation patterns, all affecting floods and droughts which in turn influence freshwater, food, homes, and livelihoods (ADB, 2012; Ali, 1999; IPCC, 2013-2014; Khan, 2012; Kummu et al., 2010; Mirza, 2003).

Karim and Mimura (2008) argue that, based on increasing flood depths and rising sea levels, Bangladesh is already being affected by climate change. Currently, almost 40 million people live in coastal Bangladesh. Loss of coastal land is predicted to reach up to $3 \%$ by the 2030 s, $6 \%$ by the 2050 s, and $13 \%$ by 2080 (Pender, 2008), suggesting that millions of Bangladeshis will be at risk and may be forced to, or may choose to, move.

These physical changes are intertwined with other socio-economic problems faced by many Bangladeshis. Hutton and Haque (2004) point out that vulnerability in Bangladesh is associated with deeply entrenched socio-economic inequities. More than half of rural households have virtually no direct access to land, even though the majority depend on agriculture. Consequently, a vast proportion of the rural poor survive on subsistence livelihoods, with little opportunity to acquire savings or assets. Irrespective of the form or speed of environmental changes, millions of Bangladeshis have problems coping with daily life now and they will have increased trouble in the future under climate change scenarios (see also Khan, 2012).

Despite the vast array of literature on Bangladesh regarding topics such as environmental change, vulnerability, and migration, it is rare for studies to explore the experiences or perceptions of local experts, from Bangladesh and India, regarding links amongst these topics. The academic field on climate change, 
environment and migration is still largely dominated by scholars from Europe, Australia and North America, even though scientists affiliated with universities in Bangladesh and India are increasingly publishing on environmentally induced migration in Bangladesh (see e.g., Das, 2011; Gray and Mueller, 2012; Stojanov and Duží, 2012; Etzold et al., 2014; Mallick and Vogt, 2014; Rahman et al., 2015; Mallick and Etzold, 2015).

Yet examining local perceptions of environmental factors for migration in South Asia is needed for identifying the discourses and representations of the relationship between environmental change and migration in the India-Bangladesh context. Such an assessment helps to combine local knowledge, witnessed experiences and existing findings from the literature, in order to gain a broader and deeper picture of migration and environmental change topics (Weber, 2010; Bardsley and Hugo, 2010).

\section{Method}

The data for this are qualitative, obtained from semi-structured, in-depth expert interviews (Mack and Woodsong, 2005) of Indian and Bangladeshi experts on topics covering environmental change, development and migration (Table 1). Experts are from academia, the public sector, the private sector, governmental institutions and NGOs.

We first reviewed existing literature about migration and environmental change, especially from or related to Bangladesh, and searched for geographical and other information about the selected region. Using this material as a basis, we chose the field work locations of Dhaka and Khulna in Bangladesh along with Delhi, West Bengal (Calcutta) and Assam (surroundings of the capital Guwahati) in India. We selected experts in these locations on the basis of the literature, including their practical work in the field of migration, development and environmental issues. We aimed for a wide spectrum of representatives from academia, government, policy-making institutions, and the non-profit sector to cover relevant fields and expertise and to gain diverse opinions and perceptions. The preliminary selected experts were contacted by email and those who responded were asked to be interviewed. We started with these contacts who agreed to be interviewed followed by experts suggested by the interviewees and others, yielding snowball sampling, a method accepted within many qualitative methods (e.g. Babbie, 2008).

The main clusters of topics for the interviews were perception of migration in general; evaluation of recent migration patterns; selection of key environmental changes and their impacts; the role of migration in sending and receiving countries; evaluation of the recent environmental situation; key environmental issues and future trends in region; and assessing whether and how experts link environmental issues with migration. Further questions on the social and environmental conditions of Bangladesh focused on manifestations of environmental change from climate variability, trends, and change through to extreme weather, often identified as having perceived higher frequencies or intensities of environmental hazards. A common thread was environmental factors affecting livelihoods and living standards in the context of potential choices to migrate or to stay. Migration strategies in response to environmental changes, or environmental changes as a trigger or impetus to stay or to leave, were also discussed.

In total, 25 respondents with various expertise, across numerous sectors and in a variety of positions, were interviewed, ten in Bangladesh and fifteen in India. Five of the respondents were female. Despite the imbalanced male-female ratio, it reflects the reality of the gender distribution amongst topic experts in both countries.

\section{Insert Table 1.}

All the interviews were conducted in English, which was not a problem because the respondents are professionals, often with extensive international experience. The grammar from the respondents was not always correct, but minimal editing has been done to the quotations, leaving some grammatical errors and stylistic inconsistencies. The interviews each lasted between 40 minutes and three hours. The respondents were guaranteed anonymity and confidentiality. The Bangladesh respondents are labeled with a BAN and the Indian respondents with IND. 


\section{Results}

\subsection{Migration connected to recent and future environmental conditions}

Most respondents expressed, in some form or another, concern about recent and future environmental conditions. They particularly highlighted climate variability and trends as having detrimental effects, including sea-level rise, floods, drought, cyclone intensity, and rain variability. Numerous comments linked recent and future environmental and climate conditions to significant concerns for livelihoods.

Respondent BAN4 summed up what many others stated, in commenting on migration and climate change:

"... three aspects: one is the frequency of the event, whatever that frequency will increase in future. The second is the intensity of an event, the hard damage of the extreme event ... Like usually the floods happen in July-August, reach September, ... the timing is going to be shifted. [This] third dimension is important in terms of its link with the production system. The flood decision timing is huge implications on an agricultural productivity. ... Now what is the projection. If there is one meter sea level rise, by end of the century, than this figure will become 25 million."

Respondent BAN7, in particular, used similar words while respondent IND1 stated: "About future trends, the impact of climate change and rise of sea level in Bangladesh...I expect increasing of migration flows...This is alternative strategy for survival." BAN2 supported this opinion: "Climate change will be a major impact on Bangladesh and it will have many difficulties for the people that live in the estuary area. One will be physical inundation, flooding of that islands that they are here, so people have to physically move out. Second will be lost of livelihood because of the crops."

Respondent BAN6 views migration as one of the possible adaptation strategies for people living in climate change impacted areas in Bangladesh: "... some of them [families] might migrate, but there is a certain lost of crop, or there is this devour, lost of land to the river, or one member of household has accident, or dies. In that case others members feel how do cope with that. One important strategy is to send members abroad, so you know the shock is absorbed."

Respondents BAN4, BAN5, IND8, IND10, and IND12 had much to say regarding observations from local areas suggesting a definite shift in climatic conditions. They particularly highlighted seasonality, precipitation, and increased flooding as being different from prior experience. They expected that similar changes in Bangladesh would increase migration.

Few patterns emerged in viewpoints based on geographic location, expertise, sector, or location. Most respondents explained that recent environmental conditions have been different from the norm according to their experience. They expected future environmental conditions to continue to worsen and to have a detrimental impact on agriculture and other livelihoods, including on migration. This view was supported by respondent BAN4 who mentioned that "due to the climate change, seasonal migration will increase as an environmental stress."

A number of respondents directly linked their observations of recent environmental conditions and expectations of future environmental conditions with contemporary climate change, namely indicating a strong contribution of human causation through global greenhouse gas emissions and land use changes (IPCC, 2013-2014). Their comments concentrated on sea-level rise as leading to migration, but other climate change factors highlighted were changes in river watercourses - especially bank river erosion and floods - and changes in monsoon and cyclone patterns. Many comments related to expectations of worse cyclones, storms, and droughts due to climate change. These patterns were linked to increased migration because, the respondents stated, Bangladeshi livelihood and economic patterns focus on farming (crops and livestock) and fishing which depend on environmental conditions. If those livelihoods are harder to pursue, then people move.

Respondent BAN3 highlighted the view that sea level rise could seriously affect " 25 to 35 per cent of the Bangladesh population." Respondent IND1 said that "About future trends, the impact of climate change and rise of sea level in Bangladesh...I expect increasing of migration flows; this is alternative strategy for survival".

But not all respondents were so clear about cause and effect regarding climate change and their 
observations. Respondent BAN2 provided nuanced comments on climate change: "So this land is always changing, along the rivers ... new islands coming up and some islands are disappearing, so people also move from island to island. ...Even a few centimeters [sea-level] rise will cause many of the islands disappearing in the near future. On the other hand, new land is forming, people are cutting down trees in the Himalayas region, so we have more and more alluvial siltation. All the silt is deposited here and the new lands are coming up." Respondent IND15 argued: "Migration is not yet related to climate change, but there are events where the weather is one factor. But to a large extent it is economic, as crops get ruined so they need to move as their agricultural land is under water and need to economically survive elsewhere".

In similar vein, respondent IND10 explained how flooding, erosion and related displacement have always been amongst the key features of the Ganges delta, now being exacerbated by climate change. Respondent BAN6 also provided a more nuanced perspective of migration that "Bangladesh is unique in the sense that many parts of the country has got river bank erosion... Many people lose out and they lose their land...They are forced [to move] some of them. Many stay behind. But some members, household members move on to find work in the city." That is, climate change is impacting migration, but some people do not move irrespective of changing environmental conditions, while others move for non-climate reasons. Related to that, two Indian respondents (IND8 and IND15) highlighted that many people migrate only temporarily after an environmental hazard: "There are river bank erosions, floods. But it leads to displacement rather over a short period of time and they come back to the same place" (IND15).

\subsection{Environmentally induced migration in wider contexts}

This study focused on perceptions of environmentally induced migration, so the responses reflected that topic. The respondents nonetheless placed environmental reasons for migrating into the context of wider migration discussions, particularly highlighting the long-standing economic and labor reasons for Bangladeshis migrating. Respondent IND3 directly noted that for Bangladeshi migration, "The most important reason would be economic... better livelihood conditions, access to land." Respondent BAN9 pointed out the frequent situation when "people do not say that they have directly come because of the river erosion or they have come because of flood. They say we have conquered better employment opportunity or in search for livelihood and etc. Upon further probing then I found what the immediate cause was, ... the erosion or flood. They lost everything ...".

Respondent BAN6 focused on Bangladeshi migrants into India by noting that "...Indian economy is rising up, there is also need for this labor, in the construction sector...the municipal corporations, they employ many people of Bangladeshi origin." This view was supported by IND15 arguing that "In Assam there is a labor deficit, why else would people move? There are not enough workers for infrastructure, as Indians do not want to come as it is slightly dangerous in Assam". According to him "cross-border migration has more to do with a lack of income than with the environment".

Respondent BAN4 connected environmental and labor migration: "there is a cyclone in the coastal area, people immediately move to the nearest urban town to seek the job, and then to the next larger town...But this is a temporary and this is a seasonal trend of migration." The implication is that environmental reasons might be a trigger or impetus for migrating - a definite push factor-but the pull factor remains better jobs. Oscillating between two or more places is also a common strategy for Bangladeshis. Respondent BAN4 added that "now they are also permanent immigrants as a last resort or a last option for community or the household when they completely lose their homestead and their livelihood system in that locality". Respondent BAN5 referred to migrants in saying "Those are rich because they have the capacity to buy land and build the house. The poorer, they go through a process [move from the place of origin]." That is, for some of the population, migration is not desired, but is nonetheless accepted when necessary.

Wider contexts than climate change were provided by Respondent BAN1 who argued that environmental conditions are the second-most important reason for Bangladeshis migrating after labor: "it is true that it [floods] is thousands years old issue... and people's movement was there too, that is one point and other things that population density increased incredibly, that is another problem, so river erosion now affects more severely, than it affected earlier." Similar comments were made for agriculture, seeing migration as a common response strategy when crops fail.

Respondents also described the historical nature of population flows between Bangladesh (in the past, East 
Pakistan and East Bengal) and India, particularly migration to West Bengal and Assam (see also Prakash, 2007; Panda, 2015). The "international" nature of this migration is relatively recent: post-1947 when India and Pakistan achieved independence. Respondent IND2 even proclaimed that each person who crosses the Indian border could be viewed as an Indian citizen, because there is no effective control of citizenship based on documentation. To a large degree, migration of Bangladeshis is accepted as the usual state of affairs. That covers both temporary and seasonal migration, usually to Assam from border areas of Bangladesh, as well as permanent migration from all over Bangladesh to areas in India with jobs or where friends and relatives already reside. Respondent IND3 stated that "Boundaries are open, you can smuggle contraband... and come across the border in four hours, even less...you can come across in one hour or so, in the small boat... and that is happening...They can cross in many parts of the border...It is obvious that India has put the border with Pakistan at higher priority than with Bangladesh. We are still in the process constructing border fencing almost 23 years after 1985."

Some of the Indian respondents (IND1, IND3, IND11) along with BAN2 believed that migration flows from Bangladesh to India have actually declined over the last three decades or so because of increasing opportunities in Bangladesh. Bangladeshi migrants have also started to move to other countries. For instance, large populations of migrant Bangladeshis now work in the Middle East due to fewer jobs and less free land in Assam, as well as stricter border protection. In this context, Respondent BAN6 described the gradual out-migration process "... workers from rural areas, they came to the urban areas to work in manufacturing sector ... they feel empowered, they have information, there is job in Malaysia, there is job in Kuwait, ... So rural to urban migrants now aspire to be international migrants, because they have got information."

That did not stop some respondents from India (IND1, IND2, IND3, IND6, and IND7) expressing fear about the ethnic and environmental future of Assam due to the Bangladeshi immigrants. They stressed the relatively high birth rate of Bangladesh immigrants in comparison to Indians in Assam - with IND3 suggesting that Assam's population is "26.6 million from 2001 census. My estimate is around 30 million, may be 30 plus" - while claiming that grazing and forest land are being taken over for farming by the immigrants. Respondent IND1 stated that for Assam, "Now the population is very high. So the sources are available there, but water resources, land resources are no longer sufficient to support lots of people getting there. It crosses the capacity of the land therefore, they want to migrate within Assam, from one area to other area to migrate." Respondents IND1, IND3, IND6, and IND7 suggested that the Bangladeshi immigrants amount, at minimum, to one third of Assam's population and that deforestation by the immigrants presents one of the biggest environmental problems. IND2 was direct in asserting that the immigrant flows are "a sort of demographic aggression" against the native Assam population.

There were also a number of Indian respondents who were critical of this negative sentiment towards Bangladeshi immigrants. IND15 for instance referred to the role of the media in fueling these negative perceptions: "In the media in Assam there is always talk of this fear of the other, it is pushed by emotions". IND11 also referred to the situation in Assam as a case of "xenophobia against immigrants". Along similar lines, an opinion article in the newspaper Tehelka maintains that attention should be provided to underlying problems, such as a lack of available land and job opportunities, instead of simply blaming the Bangladeshi immigrants (Puniyani, 2012; Panda 2015).

Finally, it is interesting to note that interviewed migration officials in the central Government of India were reluctant to connect climate change or other environmental factors to cross-border migration from Bangladesh. Instead they argued that these population flows were mainly economically driven (IND13, IND14). In contrast, governmental respondents outside the central government did discuss climate change as an increasing factor leading to cross-border migration. For example, Respondent IND8 from the Government of West Bengal noted that "Unfortunately, the Sundarbans in Bangladesh is even much poorer than the Indian part. And the border is porous. So large scale migration across border in response to climate change can not be ruled out". This finding suggests that political contexts matter in framing and perceptions of environmentally induced migration. Linking cross-border migration to climate change is a more sensitive endeavor for the central government responsible for India's climate policy and the climate change negotiations (Boas, 2015).

Furthermore, local experts from West Bengal may be more concerned as they are close to the Bangladeshi border and come from a region more directly affected by environmental impacts at the moment. As noted 
by respondent IND8: "Probably the Central Government has not yet identified climate change induced migration as a big threat because it is not going to take effect until the latter part of the century, that is the common perception. People in West Bengal are more worried because of the Sundarbans. We are watching one cyclone after another hitting the Sundarbans and their intensity is increasing day by day..."

\section{Discussion}

Respondents from both countries confirmed that there are several, interacting, reasons for migration within and from Bangladesh, while indicating that economic reasons tend to play the most significant role in decision-making regarding migration, in both pull and push factors. They noted how the combination of many other factors - historical, economic, demographic, social (e.g. health, education, family, and friends), and environmental - combine to make the decision whether or not to migrate and, if so, the destination, the speed, who goes, and whether the migration is intended to be temporary or permanent. These complexities are well-established in the migration literature (e.g. Castles \& Miller, 2009; Massey et al., 1998; Samers, 2010) as well as for Bangladesh specifically (e.g. Hadi, 1999; Khatri, 2007; Siddiqui, 2001), triangulating the experts' views on this particular question as being realistic, sensible, and grounded.

Based on the experience from Bangladesh and India reported here, the results also corroborate a principal reason for why environmental change has been on the periphery of migration literature: that there are so many other factors influencing migration (Hugo, 2008; Perch-Nielsen et al., 2008; Piguete, 2010; Stojanov, 2012). Nonetheless, most of the respondents placed recent environmental disasters and extreme weather events within the wider context climate and environmental change, connecting local experiences with climate change. Whether or not specific events or trends are indeed linked to climate change is an open question, but the experts certainly perceive that to be the case and the literature suggests that it will be increasingly likely in the future, especially for Bangladesh. Consequently, environmental reasons for migration are not to be diminished, suggesting that migration studies could engage more with environmental factors within their theoretical concepts, especially for determining the degree to which specific environmental factors do and do not play roles in migration-related decision-making.

The experts' experiences and perceptions provided two specific ways forward. First, a focus on the role of environmental change in economic- or labor-related migration decision-making. Experiences such as floods, droughts, and water/land salination might undermine livelihoods, forming the impetus to move as part of deeper desires to seek better livelihood opportunities. Second, instances were raised where the main or sole reason for migrating was inability to cope with environmental changes, whether rapid such as cyclones or longer-term such as changed seasonality or precipitation patterns. Again, the expert views on these matters were fully in line with the literature, which extensively covers forced migration due to weather-related environmental hazards such as cyclones (e.g. Paul et al., 2010), other environmental hazards such as volcanic eruptions (Tobin and Whiteford, 2006), and longer-term creeping changes such as land use (Glantz, 1999). Third, the experts' perception was that environmental impacts on internal and cross-border migration were gradually being exacerbated due to climate change's effects.

It was nonetheless highlighted that such climate change-related migration takes place within wider migration contexts and cannot be seen as separate from other social-economic forces. In fact, all three points converged to the baseline that environmental changes are one factor amongst many influencing migration. Even for point two above, in which inability to cope with environmental changes was the main or sole reason for migrating, this inability to cope needs to be seen within wider social and economic contexts. For instance, resource allocation, inequity, and prejudice can interfere with coping ability. The experts' experiences and perceptions for this baseline match that of the literature.

By presenting balanced discussion, the experts also provide a more nuanced view that challenges the rhetoric about hordes of "climate change refugees" ready to flee climate catastrophe, a viewpoint which has been critiqued and shown to lack an empirical basis (Baldwin, 2014; Bettini, 2013; Hartmann, 2010). Instead, climate change and migration due mainly to environmental changes are neither sidelined nor dominating.

As with studies factoring climate change into wider views of migration, the experts here looked beyond a direct cause-effect connection, instead describing a more complex series of linkages. In particular, sea-level rise connects to greater intensity and frequency of inundation along with erosion which, through a complex 
interplay with livelihoods and poverty, can lead to migration for those who can afford to do so. This view matches well with literature describing migration and return decisions in the context of livelihoods (e.g. Tobin and Whiteford, 2006 and, for Bangladesh, Penning-Rowsell et al., 2013), suggesting that if the ability to cope with the environmental change existed, then many would not consider migration as an option. The decision process works in tandem with migration being an ever-present option for those seeking better livelihoods or simply opportunities to send remittances back to their families (e.g. Hadi, 1999 and Barai 2012 for Bangladesh).

In fact, short-term migration, permanent labor migration, and circular migration are all standard coping strategies under multiple scenarios and for improving quality of life. Environmental factors are not precluded as one set amongst many influencing migration decisions, nor does the situation preclude environmental factors as dominating migration decisions in some circumstances. In fact, the majority of the experts' perceptions concur with this manifold view of migration, including in the context of climate change. For Bangladeshis, despite the severe implications of climate change which could provide additional migration pressures, mobility has always been part of their livelihood strategies in Bangladesh and India.

This nuanced approach by the experts reflects the literature expressing the challenge of attributing specific causes to specific migration decisions or trends (e.g. Bardsley and Hugo, 2010; Crawford and Campbell, 2012; Massey et al., 1998). If weather or seasonal conditions change crop yields or affect livestock, it could be due to climate variability, climate trends, climate change, economic variability, economic trends, economic changes, or a combination. Irrespective, the people affected must make a livelihood decision: should they remain, should some of the family leave (and for how long), or should all of the family depart (and for how long)? There might also be geographic disparities, such as the decision being more attributable to economic than environmental factors in north Bangladesh, away from the sea, whereas sealevel rise could be the main driver of migration in the southern, coastal parts.

Caution is needed not to be too assumptive about choices made by Bangladeshi immigrants, considering the complexities in how Bangladeshis adjust to environmental hazards including storm surges and riverbank erosion (e.g. Paul, 2009; Paul et al., 2010; Penning-Rowsell et al., 2013; Shaw et al., 2013; Zaman, 1994). Additionally, the concerns displayed by some of the respondents - in terms of blaming the Bangladeshi immigrants for local problems in India and being worried about being taken over by immigrants - was in stark contrast to the more neutral views expressed in other parts of the interviews. As discussed above, the fears of undue "foreign" influence among some cohorts of Assam's population have a long historical pedigree predating the more recent environmental degradation in this area. The antagonism of some of Assam's population to Bengali "foreigners" can be traced back to the British colonial rule.

Moreover, anti-immigrant sentiments have characterized some of Assam's political movements throughout the decades, including violent insurgent groups such as ULFA (United Liberation Front of Asom). On the other hand, even though the liberation struggle of Assam was united with the Indian freedom struggle during British colonial rule, many Assamese hoped for their own independent state. Since independence has not materialized, several groups such as ULFA have been waging a low intensity war against the Indian government and using anti-immigrant sentiments to gain support.

As such, two further contexts need to be considered, to which the experts alluded. First, the dominating trend of rural-to-urban migration flows in Bangladesh (Goswami, 2010; Hadi, 1999). It seems that the Bangladeshi migrants are often more concerned about reaching urban areas with the expectation of jobs there, rather than about which particular country they end up in. Second, the economic characteristics of Bangladeshi immigrants who, in India, generally come from the middle class and middle-upper class, whereas internal immigrants also include low-income categories. The difference occurs due to affordability: people with higher socio-economic status use their resources to leave Bangladesh. Those with lower resources tend to be forced to stay in Bangladesh, even if migrating internally. Within these migration patterns, many of the more affluent migrants acquired their financial resources through migration, either themselves or a family member working temporarily in, for example, the Middle East. While climate change and other environmental reasons are expected to continue to influence migration according the experts, any migration in Bangladesh is expected to continue to conform to these established patterns. 


\section{Conclusions}

This study investigated experiences and perceptions of local experts from India and Bangladesh regarding environmentally induced migration in and from Bangladesh, especially in the context of contemporary climate change. The experts identified environmental factors as influencing migration in Bangladesh and expressed fears that climate change would have a significant influence on future migration. But they placed these factors into wider contexts, notably highlighting labor and economic reasons for migrating while describing the long-standing history of migration in Bangladesh for environmental and non-environmental reasons.

The experts' experiences and perceptions match well with the migration literature indicating that the environment, including climate change, can be a migration driver, but that the level of influence differs depending on the specific case study and timing (e.g. Black et al., 2011; Deshingkar, 2012; Hadi, 1999; Khatri, 2007; Massey et al., 2010; Siddiqui, 2001; Warner, 2011). The majority of the experts' views also match well with the critiquing literature on massive flows of 'climate change refugees' indicating subtleties and nuances regarding the understanding of migration movements (Baldwin, 2014; Baldwin et al., 2014; Bettini, 2013; Gibb \& Ford, 2012; Hartmann, 2010). These are important contributions, since much is written about environmental change, vulnerability, and migration for South Asia, especially with respect to Bangladesh and sea-level rise, but such contributions, especially the most well-known ones, predominantly come from scholars from outside these countries and mainly from more affluent countries. It is rare to find research which examines the experiences and perceptions of local experts regarding links amongst these topics. This paper further adds to the literature by including perceptions and experiences from experts who are not trained as scientists, but who are journalists or who work in the public or private sector.

The experts' views and the analysis indicate some lines of future research. First, studies of experts' perceptions and of migrants' perceptions could be combined by bringing them together in focus groups to discuss reasons for and views of migration. Such research would help to triangulate the data from each group separately yielding further insights into how local experiences and decisions fit into wider trends and patterns, while giving the groups the opportunity to compare and contrast their experiences with each other. Second, with some prejudices emerging from some of the expert respondents, it would be useful to explore those further to determine how much those prejudices do or do not influence their other remarks. For example, is it possible that environmental factors forcing migration are downplayed due to anti-immigrant hostility in order to try to blame the migrants for moving? How much might the international literature reflect or counter any such biases?

Third, it is important to highlight local views on environmentally related migration and non-migration processes to counter an affluent country bias in the literature on climate change and migration. Alarmist discourses about climate-related mass migration and resulting insecurity, conflict and chaos in areas such as India and Bangladesh often find their origin in the more affluent countries (Boas, 2014). Without immediately suggesting that groups are necessarily right or wrong, the comparison, contrast, and balance is important to produce a fuller, more robust picture. Fourth, what are the policy implications for addressing migration induced by, linked to, or influenced by climate change when such migration occurs within much wider migration contexts? Could discouraging environmentally induced migration, or supporting these immigrants to settle as near their original home as feasible, end up inhibiting remittances and other livelihood-related migration, which have long been a necessary part of Bangladeshi livelihoods (e.g. Hatemi-J \& Uddin, 2014; Sikder \& Ballis, 2013)?

Migration is, and always has been, a complex process affected my multiple factors (Bardsley \& Hugo, 2010; Castles \& Miller, 2009; Massey et al., 1998; Samers, 2010). With environmental conditions changing rapidly, and with the expectation that Bangladesh will be significantly affected by climate change, different scenarios of environmentally induced migration ought to be explored. As the local experts indicate, environmentally induced migration should not be assumed to be inevitable or dominating, a position which matches the wider literature.

\section{Acknowledgements}

The authors are thankful for the support from anonymous respondents and for their willingness to share their opinion on researched topics. 


\section{References}

ADB (2012) Addressing Climate Change and Migration in Asia and Pacific. Final Report. Asian Development Bank, Mandaluyong City.

Afifi T, Milan A, Etzold B, Schraven B, Rademacher-Schulz C, Sakdapolrak P, Reiff A, van der Geest K, Warner K (2015) Human mobility in response to rainfall variability: opportunities for migration as a successful adaptation strategy in eight case studies. Migration and Development, 5 (2), 254-274.

Ahmed I (2008) Environmental Refugees and Environmental Distress Migration as a Security Challenge for India and Bangladesh. In Afes-Press HG, Behera NC, Kameri-Mbote P, Grin J, Oswald Spring Ú, Chourou B, Mesjasz C, Krummenacher H. (eds) Facing Global Environmental Change: Environmental, Human, Energy, Food, Health and Water Security Concepts, 295-308. Springer, Berlin.

Ali A (1999) Climate change impacts and adaptation assessment in Bangladesh. Climate Research 12 (2-3), 109-16.

Babbie, E (2008) The Basics of Social Research, 4th ed. Thomson Wadsworth, Belmont, CA.

Baldwin W A (2014) The political theologies of climate change-induced migration. Critical Studies on Security 2, 210-22.

Baldwin W A, Methmann C, Rothe D (2014) Securitizing 'climate refugees' the futurology of climateinduced migration. Critical Studies on Security 2, 121-30.

Barai MK (2012) Development Dynamics of Remittances in Bangladesh. SAGE Open 2 (1), 1-13.

Bardsley DK, Hugo GJ (2010) Migration and climate change: examining thresholds of change to guide effective adaptation decision-making. Population and Environment 32 (2-3), 238-62.

Bettini G (2013) Climate Barbarians at the Gate? A critique of apocalyptic narratives on 'climate refugees'. Geoforum 45 (1), 63-72.

Black R, Bennett SRG, Thomas SM, Beddington JR (2011) Migration as adaptation. Nature 478: 477-9.

Boas I (2014) Where is the South $\mathrm{n}$ security discourse on climate change. Critical Studies on Security 2(2), $148-161$.

Boas I (2015) Climate Migration and Security. Securitisation as a strategy in climate change politics. Routledge, New York.

Bronen, R. and Chapin III, F.S. (2013), "Adaptive governance and institutional strategies for climateinduced community relocations in Alaska", PNAS, 110 (23): 9320-9325.

Campbell KM, Guiledge J, McNeill JR, Podesta J, Ogden P, Fuerth I, Woolsey RJ, Lennon TJ, Smith J, Weitz R, Mix D (2007) The age of consequences: The foreign policy and national security implications of global climate change. Washington: Center for New American Security and Center for Strategic \& International Studies.

Castles S, Miller MJ (2009) The Age of Migration: International Population Movements in the Modern World. Palgrave Macmillan, London.

Census of India (2011) Drop-in-Article on Census: Migration. Government of India, New Delhi.

CNA (2007) National security and the threat of climate change. Military Advisory Board Virginia: The CNA Corporation.

Crawford MH, Campbell BC (eds) (2012) Causes and Consequences of Human Migration: An Evolutionary Perspective. Cambridge University Press, Cambridge.

Das SK (2011) Wrestling with my Shadow': The State and the Immigratn Muslims in Contemporary West Bengal. Dasgupta A, Togawa M, Barkat A (eds.), Minorities and the State. Changing social and political 
landscape of Bengal, 39-65, Sage Publications, New Delhi.

Dasgupta A, Togawa M, Barkat A (2011) Minorities and the State. Changing social and political landscape of Bengal. Sage Publications, New Delhi.

Dass SK (1980) Immigration and Demographic Transformation of Assam, 1891-1981. Economic and Political Weekly, 15 (19), 850-859.

Deshingkar D (2012) Environmental risk, resilience and migration: implication for natural resource management and agriculture. Environmental Research Letters, 7 (1), 015603 doi:10.1088/17489326/7/1/015603

Donato KM, Carrico AR, Sisk B, Piya B (2016) Different but the Same: How Legal Status Affects International Migration from Bangladesh. The Annals of the American Academy of Political and Social Science, 666 (1): 203-18.

Etzold B, Ahmed AU, Hassan SR, Neelormi S (2014) Clouds gather in the sky, but no rain falls. Vulnerability to rainfall variability and food insecurity in Northern Bangladesh and its effects on migration. Climate and Development, 6 (1): 18-27.

Felli R, Castree N (2012) Neoliberalising adaptation to environmental change: foresight or foreclosure? Environment and Planning A 44 (1): 1-4.

Foresight (2011) Migration and Global Environmental Change. Future Challenges and Opportunities. Final Project Report. UK Government Office for Science, London.

GACGC (2007) World in Transition: Climate Change as a Security Risk. Berlin: German Advisory Council on Global Change.

Gibb C, Ford J (2010) Should the United Nations Framework Convention on Climate Change recognize climate migrants? Environmental Research Letters 7 (4), 045601 doi:10.1088/1748-9326/7/4/045601.

Glantz M H (ed.) (1999) Creeping Environmental Problems and Sustainable Development in the Aral Sea. Cambridge University Press, Cambridge.

Goswami N (2010) Bangladeshi Illegal Migration into Assam: Issues and Concerns from the Field. Institute for Defence Studies and Analysis, New Delhi.

Gray CL, Mueller V. (2012) Natural disasters and population mobility in Bangladesh. PNAS, 109 (16): 6000-6005.

Hadi A (1999) Overseas migration and the well-being of those left behind in rural communities of Bangladesh. Asia Pacific Population Journal 14 (1), 43-58.

Hartmann B (2010) Rethinking climate refugees and climate conflict: rhetoric, reality and the politics of policy discourse. Journal of International Development 22 (2), 233-46.

Hatemi-J A, Uddin GS (2014) On the causal nexus of remittances and poverty reduction in Bangladesh. Applied Economics 46 (4), 374-82.

Hugo G (2008) Migration, Development and Environment. IOM (International Organization for Migration), Geneva.

Hutton D, Haque, CE (2004) Human Vulnerability, Dislocation And Resettlement: Adaptation Processes Of River-Bank Erosion-Induced Displaces In Bangladesh. Disasters 28 (1), 41-62.

IPCC (2013-2014) Fifth assessment report. IPCC (Intergovernmental Panel on Climate Change), Geneva.

Karim MF, Mimura N (2008) Impacts of climate change and sea-level rise on cyclonic storm surge floods in Bangladesh. Global Environmental Change 18 (3), 490-500.

Kelman I, Stojanov R, Khan S, Gila OA, Duží B, Vikhrov D (2015) Viewpoint paper. Islander mobilities: any change from climate change? International Journal of Global Warming, 8 (4), 584-602.

Khan A (2012) Creative Adaptation: Bangladesh's Resilience to Flooding in a Changing Climate. Lamadrid A, Kelman I (eds), Climate Change Modeling for Local Adaptation in the Hindu Kush Himalayan Region, 159-75, Emerald, Bingley. 
Khatri SK (2007) Labour Migration, Employment and Poverty Alleviation in South Asia. South Asia Centre for Policy Studies (SACEPS) and Friedrich Ebert Stiftung (FES), Kathmandu and Bonn.

Kumar A (2010) Illegal Bangladeshi Migration to India: Impact on Internal Security. Strategic Analysis 35 (1), 106-19.

Kummu M, Ward PJ, de Moel H, Varis O (2010) Is physical water scarcity a new phenomenon? Global assessment of water shortage over the last two millennia. Environmental Research Letters 5 (3), 034006 doi:10.1088/1748-9326/5/3/034006.

Mack N, Woodsong C (2005) Qualitative Research Methods: A Data Collector's Field Guide. Family Health International, Durham, North Carolina.

Mallick B, Etzold B (2015) Environment, Migration and Adaptation. Evidence and Politics of Climate Change in Bangladesh. A H Development Publishing House, Dhaka.

Mallick B, Vogt J (2014) Population displacement after cyclone and its consequences: empirical evidence from coastal Bangladesh. Natural Hazards, 73 (2), 191-212.

Massey DM, Arango J, Hugo G, Kouaouci A, Taylor JE (1998) Worlds in Motion: Understanding International Migration at the End of the Millennium. Clarendon Press, Oxford.

Massey DS, Axinn GA, Ghirime DJ (2010) Environmental change and out-migration: evidence from Nepal. Population and Environment 32(2/3), 109-36..

McAdam J and Saul B (2010) Displacement with Dignity: International Law and Policy Responses to Climate Change Migration and Security in Bangladesh. Legal Studies Research Paper, No. 10/113, Sydney Law School, Sydney.

Mirza MMQ (2003) The Implications of Climate Change on Floods of the Ganges, Brahmaputra and Meghna Rivers in Bangladesh. Climatic Change 57 (3), 287-318.

Nath BK, Nath DC, Bhattacharya LB (2012) Undocumented Migration from in the State of Assam in the Northeast Asia: Estimates since 1971 to 2001. Asian Journal of Applied Sciences 5 (3), 164-73.

Otto-Banaszak I, Matczak P, Wesseler J, Weschung F (2011) Different perceptions of adaptation to climate change: a mental model approach applied to the evidence from expert interviews. Regional Environmental Change 11 (2), 217-228.

Panda A (2015) Climate Induced Migration and Interdependent Vulnerabilities Between Bangladesh and India. In: Mallick B, Etzold B (eds) Environment, Migration and Adaptation. Evidence and Politics of Climate Change in Bangladesh. A H Development Publishing House, Dhaka, p. 195-212.

Paul BK (2009) Why relatively fewer people died? The case of Bangladesh's Cyclone Sidr. Natural Hazards 50 (2), 289-304.

Paul BK, Rashid H, Islam MS, Hunt LM (2010) Cyclone evacuation in Bangladesh: Tropical cyclones Gorky (1991) vs. Sidr (2007). Environmental Hazards 9 (1), 89-101.

Pender J (2008) Community-led Adaptation in Bangladesh. Forced Migration Review 31, 54-5.

Penning-Rowsell EC, Sultana P, Thompson PM (2013) The 'last resort'? Population movement in response to climate-related hazards in Bangladesh. Environmental Science and Policy 27s, s44-s59.

Perch-Nielsen SL, Bättig MB, Imboden D (2008) Exploring the link between climate change and migration. Climatic Change 91 (3-4), 375-93.

Piguet E, Pécoud A, de Guchteneire P (2011) Introduction: Migration and climate change. p. 1-34. In: Piguet E, Pécoud A, de Guchteneire P (eds.) Climate change and migration. Cambridge, University Press, $429 \mathrm{pp}$.

Piguete E (2010) Linking climate change, environmental degradation, and migration: a methodological overview. WIREs Climate Change 1 (4), 517-24.

Prakash CV (2007) Foreigners and Outsiders in Assam - A Bugbear or a Curse? In Prakash V (ed) Encyclopedia of North-East India, Volume 2, 741-816. Atlantic, New Delhi. 
Puniyani R (2012) Assam riots: real issue is development. Tehelka, 31 July 2012. Available at: http://www.tehelka.com/story_main53.asp?filename=Fw310712Assam.asp (last visit 3 July 2013).

Rademacher-Schulz C, Afifi T, Warner K, Rosenfeld T, Milan A, Etzold B, and Sakdapolrak P (2012) Rainfall variability, food security and human mobility. An approach for generating empirical evidence. Intersections No. 10. Bonn: UNU-EHS, 109 pp.

Rahman MK, Paul BK, Curtis A, Schmidlin TW (2015) Linking Coastal Disasters and Migration: A Case Study of Kutubdia Island, Bangladesh. The Professional Geographer, 67(2) 218-228.

Ratha D, De S, Dervisevic E, Eigen-Zucchi C, Plaza S, Schuettler K, Wyss H, Yi S, and Yousefi SR (2014) Migration and Development Brief 23. Migration and Remittances: Recent Developments and Outlook. The World Bank, October 6, 2014.

Saadi S (2003) Flood Induced Displacement: A Case Study of Jamalpur. In Abrar CR, Lama MP (eds) Displaced Within Homelands. The IDPs of Bangladesh and the Region, 33-52. Refugee and Migratory Movements Research Unit, Dhaka.

Saha SK (2016) Cyclone Aila, livelihood stress, and migration: empirical evidence from coastal Bangladesh. Disasters, forthcoming, doi:10.1111/disa.12214

Samers M (2010) Migration. Routledge, London.

Shaw R, Mallick F, Islam A (eds) (2013) Climate Change Adaptation Actions in Bangladesh. Springer, Heidelberg.

Siddiqui T (2001) Transcending boundaries: labour migration of women from Bangladesh. Dhaka University Press, Dhaka.

Sikder MJU, Ballis PH (2013) Remittances and life chances: a study of migrant households in rural Bangladesh. Migration and Development 2 (2), 261-85.

Singh R (2009) ULFA's niche war. Indian Defence Review, 24 (1), http://www.indiandefencereview.com/news/ulfas-niche-war

Sinha SP (2011) Northeast: the future prospects. In: Lost Opportunities: 50 Years Of Insurgency In The North-East And India's Response. Lancer Publishers, New Delhi.

Smith DM, Scaife AA, Kirtman BP (2012) What is the current state of scientific knowledge with regard to seasonal and decadal forecasting? Environmental Research Letters 7 (1), 015602 doi:10.1088/1748$9326 / 7 / 1 / 015602$

Stojanov R (2012) Environmental Change and Migration. In Elliot D, Segal UA (eds) Refugees Worldwide. Volume One: A global Perspective, 55-89. Praeger, Santa Barbara.

Stojanov R, Duží, B. (2012) When History and River Break the Border in South Asia: Environmental Migration and Policy Dilemma. In: Rahman Md M.; Ullah AKM A. (eds): Asian Migration Policy: South, Southeast and East Asia. New York: Nova Science Publishers. pp. 201-234.

Stojanov R, Kelman I, Shen S, Duží B, Upadhyay H, Vikhrov D, Lingaraj GJ, Mishra A (2014) Contextualising Typologies of Environmentally Induced Population Movement. Disaster Prevention and Management: An International Journal, 23 (5): 508-523.

Tobin GA, Whiteford LM (2006) Community resilience and volcano hazard: the eruption of Tungurahua and evacuation of the Faldas in Ecuador. Disasters 26 (1), 28-48.

Upadhyaya P (2006) Securitization Matrix in South Asia: Bangladeshi Migrants as Enemy Alien. Caballero-Anthony M, Emmers R, and Acharya A, Non-Traditional Security in Asia. Dilemmas in Securitization, 13-19 Ashgate Publishing, Hampshire.

Upadhyay H, Kelman I, Lingaraj GJ, Arabinda M, Shreve C, Stojanov R (2015) Conceptualizing and Contextualizing Research and Policy for Links between Climate Change and Migration. International Journal of Climate Change Strategies and Management, 7 (3), 394-417.

Van Schendel W (2005) The Bengal Borderland. Beyond State and Nation in South Asia. Anthem Press, London. 
Warner K (2011) Environmental change and migration: methodological considerations from groundbreaking global survey. Population and Environment 33 (1), 3-27.

Weber EU (2010) What shapes perception of climate change? WIREs Climate Change 1 (3), 332-42.

Weiner M (1978) Sons of the Soil: Migration and Ethnic Conflict in India. Princeton University Press, Princeton, NJ.

Weiner M (1983) The Political Demography of Assam's Anti-Immigrant Movement. Population and Development Review 9 (2), 279-92.

Zaman MQ (1991) The displaced poor and resettlement policies in Bangladesh. Disasters 15 (2), 117-25.

Zaman MQ (1994) The Social and Political Context of Adjustment to Riverbank Erosion Hazard and Population Resettlement in Bangladesh. Human Organization 48 (3), 196-205.

\section{Tables}

Table 1: List of respondents

\begin{tabular}{|c|c|c|c|c|c|c|}
\hline \# & Country & Expertise & Gender & Location & Sector & Position \\
\hline BAN1 & Bangladesh & $\begin{array}{l}\text { Anthropolo } \\
\text { gist }\end{array}$ & $\mathrm{F}$ & Dhaka & academia & lecturer \\
\hline BAN2 & Bangladesh & $\begin{array}{c}\text { Environmen } \\
\mathrm{t}\end{array}$ & M & Dhaka & private & consultant \\
\hline BAN3 & Bangladesh & $\begin{array}{c}\text { Environmen } \\
t\end{array}$ & M & Dhaka & $\begin{array}{l}\text { non-profit } \\
\text { and non- } \\
\text { government } \\
\text { al }\end{array}$ & $\begin{array}{l}\text { director of the } \\
\text { organization }\end{array}$ \\
\hline BAN4 & Bangladesh & $\begin{array}{l}\text { Climate } \\
\text { change }\end{array}$ & M & Dhaka & $\begin{array}{l}\text { non-profit } \\
\text { and non- } \\
\text { government } \\
\text { al }\end{array}$ & $\begin{array}{l}\text { research } \\
\text { officer }\end{array}$ \\
\hline BAN5 & Bangladesh & $\begin{array}{c}\text { Social } \\
\text { sciences }\end{array}$ & M & Dhaka & $\begin{array}{l}\text { non-profit } \\
\text { and non- } \\
\text { government } \\
\text { al }\end{array}$ & $\begin{array}{c}\text { research } \\
\text { officer }\end{array}$ \\
\hline BAN6 & Bangladesh & Migration & M & Dhaka & academy & director \\
\hline BAN7 & Bangladesh & $\begin{array}{c}\text { Environmen } \\
\text { tal hazards }\end{array}$ & M & Khulna & $\begin{array}{l}\text { non-profit } \\
\text { and non- } \\
\text { government } \\
\text { al }\end{array}$ & $\begin{array}{l}\text { program } \\
\text { officer }\end{array}$ \\
\hline BAN8 & Bangladesh & Migration & M & $\begin{array}{c}\text { an } \\
\text { expatriate in } \\
\text { Canada }\end{array}$ & academia & research fellow \\
\hline BAN9 & Bangladesh & $\begin{array}{c}\text { Developme } \\
\text { nt studies }\end{array}$ & $\mathrm{F}$ & Dhaka & $\begin{array}{c}\text { public } \\
\text { (governmen } \\
\text { t) }\end{array}$ & research fellow \\
\hline BAN10 & Bangladesh & $\begin{array}{l}\text { Developme } \\
\text { nt practice }\end{array}$ & M & Khulna & $\begin{array}{l}\text { non-profit } \\
\text { and non- } \\
\text { government }\end{array}$ & director \\
\hline IND1 & India & $\begin{array}{l}\text { Environmen } \\
\text { t, geography }\end{array}$ & $\mathrm{F}$ & Guwahati & academia & professor \\
\hline IND2 & India & $\begin{array}{l}\text { GIS, Land } \\
\text { change } \\
\text { science }\end{array}$ & M & Guwahati & academia & lecturer \\
\hline
\end{tabular}




\begin{tabular}{|c|c|c|c|c|c|c|}
\hline IND3 & India & $\begin{array}{l}\text { Population } \\
\text { Geography }\end{array}$ & M & Guwahati & academia & reader \\
\hline IND4 & India & Migration & $\mathrm{F}$ & Guwahati & academia & phd student \\
\hline IND5 & India & Geography & M & Guwahati & academia & professor \\
\hline IND6 & India & $\begin{array}{l}\text { Population } \\
\text { studies }\end{array}$ & M & Balasore & academia & lecturer \\
\hline IND7 & India & $\begin{array}{l}\text { Developme } \\
\text { nt studies }\end{array}$ & M & Trivandrum & academia & phd scholar \\
\hline IND8 & India & environment & M & Kolkata & public & $\begin{array}{l}\text { Senior } \\
\text { government } \\
\text { official }\end{array}$ \\
\hline IND9 & India & $\begin{array}{c}\text { Environmen } \\
t \text { and } \\
\text { developmen } \\
t\end{array}$ & M & Kolkata & public & $\begin{array}{c}\text { Senior } \\
\text { government } \\
\text { official }\end{array}$ \\
\hline IND10 & India & $\begin{array}{c}\text { Climate } \\
\text { adaptation }\end{array}$ & M & Kolkata & private & NGO \\
\hline IND11 & India & $\begin{array}{l}\text { Political } \\
\text { science }\end{array}$ & M & Kolkata & academia & Professor \\
\hline IND12 & India & Migration & $\mathrm{F}$ & Delhi & private & $\begin{array}{l}\text { Think tank } \\
\text { researcher }\end{array}$ \\
\hline IND13 & India & Migration & M & Delhi & public & $\begin{array}{c}\text { Senior } \\
\text { government } \\
\text { official }\end{array}$ \\
\hline IND14 & India & Migration & M & Delhi & public & $\begin{array}{c}\text { Senior } \\
\text { government } \\
\text { official }\end{array}$ \\
\hline IND15 & India & Migration & M & Delhi & $\begin{array}{l}\text { academia/ } \\
\text { Private }\end{array}$ & $\begin{array}{l}\text { Professor and } \\
\text { journalist }\end{array}$ \\
\hline
\end{tabular}

